\title{
Business and Cultural Differences Between Origin and Destination Countries in Export Performance
}

\author{
Mahdokht Safarpour ${ }^{1}$, Seyed Mohammad Mirmahdi Komejani ${ }^{2}$ \\ Islamic Azad University, South Tehran Branch, Faculty of Management, Tehran, Iran
}

\begin{abstract}
In recent years, the survival of international business organizations has been closely tied to a successful export process. In this regard, one of the most prominent operational steps is to rigorously consider to the cultural structure of the destination country to enter the competitive markets.
\end{abstract}

The main purpose of this study is to investigate business and cultural diversity between origin and destination countries in export performance. The research method is a practical correlative descriptive survey and has been performed through a case study. The target statistical population has been amongst four Iranian household appliances companies (Electro Steel, Pars Khazar, Emersun and Barfab) that have been acting in export markets for years. The hypotheses have been investigating whether there is a significant relation between business differences, cultural differences, human capital and export performance or not. They have been tested by the structural equation modelling through SPSS and Smart PLS. A standard questionnaire with 27 questions has been used for collecting data whose validity and reliability has been confirmed. The results, based on a survey of 126 executive and export managers and board members, illustrate that accomplishment of organizational export goals is strongly affected by cultural diversity and commercial differences between export origin and import destination and also human capital separately. Likewise, it has been concluded that there is a meaningful direct relation between human capital and cultural and business differences. In addition, the role of mediator human capital among cultural and business differences and export performance of companies is not accepted.

Keywords: international business, cultural differences, intellectual capital, export performance. 
International Conference on Research in Management \& Economics

Serbia | Belgrade | December 15-17, 2018

\section{Introduction}

Globalization, as a novel phenomenon in the contemporary world is caused distinctive complicated competitions on global market where international companies would be volved (Ghosh, 2011; Boskov and Lazarovski, 2011). Based on this distinction, it is essential that current companies pay attention to the keyconcepts of modern commerce such as multiculturalism and transnational (Shome, 2012). In this way, companies set their goals beyond national trade, on a global scale (Levitt, 1983). At the beginning, this requires assigning adequate resources to exploit opportunities and potential, utilize advanced technology and avoid waste of time, cost and energy, to achieve the goal. In this regard, company will attain financial and credit growth meaningfully with a targeted plan in medium-term (Samimi and Janatabadi, 2014). Indeed, household appliances are an attractive industry for the sizable majority of people who are constantly connecting with this market to provide their necessary equipment (Koklic and Vida, 2009). In this situation, by managing technology and innovation, executive managers would react to industrial developments as quickly as possible and produce goods appropriate commodities based on customer demands at any time (Gülsoy et al., 2012). For this purpose, we have conducted a case study on the evaluation of the export performance of some Iranian home appliances companies considering their cultural and business limitations and strategies.

\section{Literature Review}

\section{1- Cultural differences}

The culture of a community is a mix of people's perceptions, beliefs and knowledge of a geographic region over time (Macionis, 2011). As a matter of fact, culture is a phenomenon which cannot be changed easily because perceptual attributes of individuals evolve during the time gradually, and it depends on the environmental, climatic, political and social conditions around an area. Clearly, conventional beliefs have been strongly influenced by cultural developments due to raising awareness of people in the digital era (Konya, 2006; Ng and Hynie, 2014). In conclusion, recognizing the distinguishing features of the culture of people in import destinations is essential in international trade and it should come under close scrutiny since it is a vital step towards efficient business deals over the borders (Menezes, 2014). Senior managers should try to adapt their goods and services with local needs and opinions through advanced market research (Guffey, 2005). Without a doubt, using marketing research help companies come to realization of specific cultural infrastructure of new places that have been surveyed through empirical evidence obtained (Malhotra and Peterson, 2001). 
International Conference on Research in Management \& Economics

Serbia | Belgrade | December 15-17, 2018

\section{2- Business differences}

Business differences in various countries have been expressed as the efforts of nations to maintain and enhance their domestic capital. In this regard, governments, through the support of manufacturing industries and by providing economic facilities, seek to

expand the volume of export transactions and reduce imports (Zakaria, 2014; Hooker, 2012).

Since companies can spot gaps between themselves and their competitors in the global business, they need to focus on the competitive advantages of their products considerably (Hoyer et al., 2010).

In this way, widespread advertising and social media marketing is a practical program for describing goods accurately and protecting brand image in the new markets. Furthermore, loyalty programs persuade loyal customers who make purchases frequently to introduce brand to others via word of mouth marketing (Gilfoil et al. 2015). In other words, the best quality of products and services and using competitive pricing strategy can help attracting the middle class of society which include the largest portion of the regional markets (De Toni et al. 2017).

\section{3- Human capital}

Human capital as one of the three main components of intellectual capital is the capability of human to meet challenges of uncertainty and unknown conditions (Goldin, 2016; Ali et al., 2018). In different societies, potential candidates are available to work in various occupations. But, at first, they are considered as unskilled labour.

Professional education and proper management can transform young workface to worth capital. International business organizations should put heavy strains on human resources, invest on hidden talents and guide their knowledge in order to exploit their potential (Souleh, 2014). On the other hand, the composition of human capital creativity with managerial and executive skills provides an ideal status in export performance. Because human solutions will be a logical and prompt answer to unpredictable issues in international trade (Haq and Luqman, 2014). As a result, the appropriate utilization of human capital will follow a remarkable economic growth in successful export efficiency (Ali et al., 2018).

\section{4- Export performance}

Successful export provides prominent benefits for people. Firstly, in the macroeconomic perspective, export activity as a national capital is the main step towards GDP growth which has promoted job creation directly. Likewise, it is an efficient financial process that through the injection of foreign exchange resources causes a monetary equilibrium. Because selling delivered goods to destination is profitable and can also attract foreign capital in different types of investments such as buying cooperation stocks or contributing to creation of a new manufacturing line (Kutan and Vuksin, 2007; Leonidou, 2004; Kahiya and Dean, 2014). To clarify this point, findings obtained indicate that developing countries are increasing their foreign direct investment flows; however, in the current situation the supply and demand elasticity of industrial goods such as domestic appliances made in developed countries is more than 
International Conference on Research in Management \& Economics Serbia | Belgrade | December 15-17, 2018

developing countries (Mitic and Ivic, 2016; Kilavuz and Topcu, 2012). A distinguishing aspect of export is to introduce and transfer the beliefs and customs of an area to other countries. Hence, international organizations have critical responsibility because a weak or unsuccessful export performance will have negative cultural and economic effects for the origin country which will not be usually compensated in a short term (Menezes, 2014; Munch and Schaur, 2014).

\section{Research Methodology}

The purpose research of this study is considered a practical work, from the nature point of view is considered a qualitative and from the content perspective is a correlative research. Concerning the research objective, this work is considered a practical correlative descriptive survey research and has been performed through a case study. Initially, the theoretical literature and research background have been investigated, collected and in continuous then a conceptual model is presented.

\section{Research Conceptual Model}

The conceptual model (Fig. 1) is prepared by combining the principles of international trade and cultural beliefs in export performance in order to measure the impact of these factors on the international success of business organizations which has been mentioned in the studies of Griffith and Dimitrova, 2014, Contractor and Mudambi, 2008 and Tesfom and Lutz, 2006 in different models.

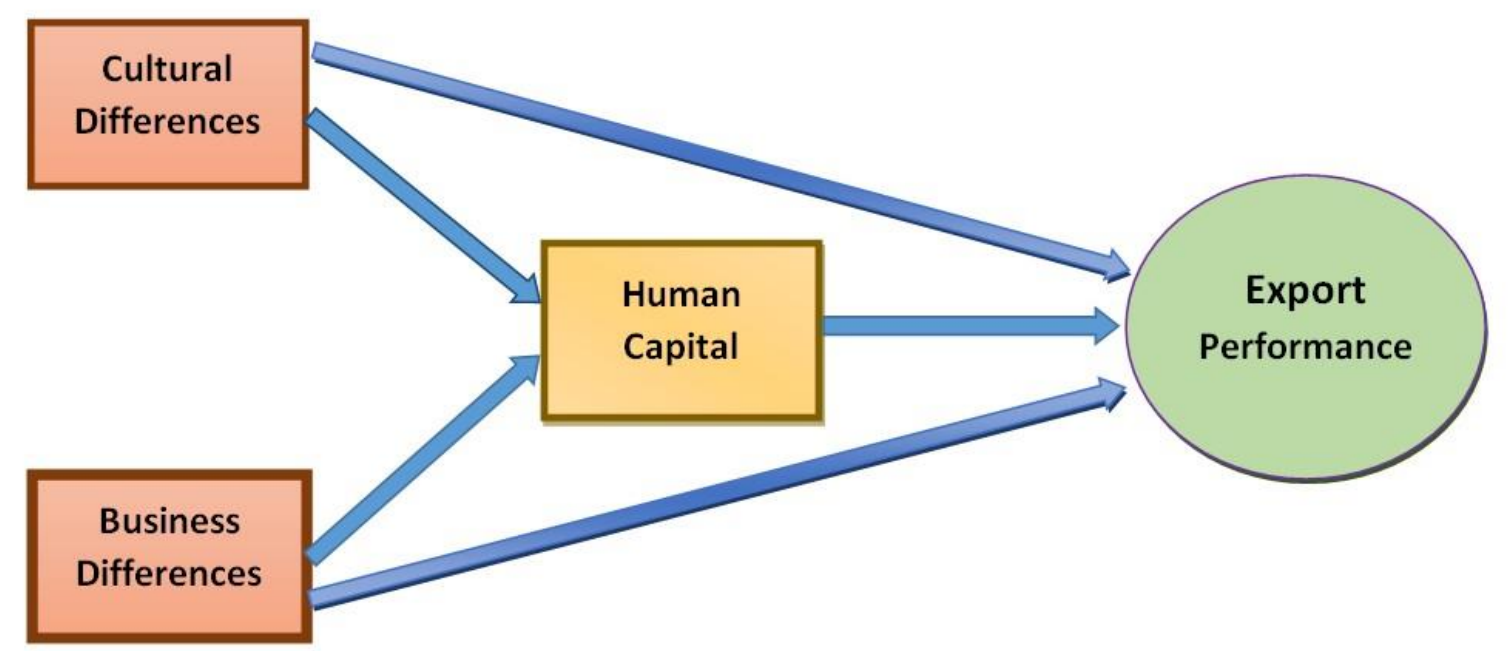

Fig. 1: The Research Conceptual Model

\section{Research Hypotheses}


International Conference on Research in Management \& Economics Serbia | Belgrade | December 15-17, 2018

Based on the conceptual model, the following hypotheses have been investigated:

1. There is a significant relation between cultural diversity at the origin and destination countries and capital human.

2. There is a significant relation between business differences at the origin and destination countries and capital human.

3. There is a significant relation between cultural diversity at the origin and destination countries and export performance.

4. There is a significant relation between business differences at the origin and destination countries and export performance.

5. There is a significant relation between human capital and export performance.

6. There is a significant relation as the role of mediator human capital among cultural diversity and export performance.

7. There is a significant relation as the role of mediator human capital among business differences and export performance.

\section{Data Collection Method}

The statistical population of this study is comprised of four Iranian home appliances companies (Electro Steel, Pars Khazar, Emersun and Barfab) as case studies which they have been operating in the export trade.

The selected sample in this research has been 126 including executive, marketing and export managers and board members. Due to a limited number of the population and the availability of all of them, we have studied all the people of statistical population by using the census method. Firstly, two qualitative and quantitative methods have been considered. The qualitative assessment provides by asking the marketing professors and export experts to collect their feedback about the tools.

In the quantitative approach, a standard questionnaire has been used after confirming validity and reliability that consists of 27 questions with a five-point Likert scale response system. In terms of confirming content validity, we've turned to academic professors and marketing experts to get their advice. Its reliability has been calculated and confirmed by Cronbach's alpha method.

\section{Analysis of Data}


International Conference on Research in Management \& Economics Serbia | Belgrade | December 15-17, 2018

\section{1- Descriptive statistics}

The main demographic features of the studied people are shown in Table 1.

Table 1: sample key demographic features

\begin{tabular}{||l|l|l|l||}
\hline \multicolumn{2}{||l}{ Sample characteristics } & Frequency & Percentage \\
\hline \hline \multirow{2}{*}{ Gender } & Female & 30 & 23.8 \\
\cline { 2 - 4 } & Male & 96 & 76.2 \\
\hline \hline \multirow{2}{*}{$\begin{array}{l}\text { Age } \\
\text { range }\end{array}$} & $25-35$ years & 42 & 33.3 \\
\cline { 2 - 4 } & $35-45$ years & 29 & 23 \\
\cline { 2 - 4 } & Above 45 years & 55 & 43.7 \\
\hline \hline \multirow{2}{*}{$\begin{array}{l}\text { Academic } \\
\text { level }\end{array}$} & Undergraduate & 52 & 41.2 \\
\cline { 2 - 5 } & Graduate & 56 & 44.4 \\
\cline { 2 - 4 } & PhD & 18 & 14.4 \\
\hline \hline
\end{tabular}

Table 2: central and dispersion indices of quantitative variables

\begin{tabular}{|l|l|c|c|c|}
\hline variable & average & the lowest amount & the highest amount & standard deviation \\
\hline Human capital & 3.841 & 1 & 4.70 & 0.780 \\
\hline Export performance & 2.930 & 1 & 4.60 & 0.954 \\
\hline Cultural Differences & 4.014 & 1 & 4.41 & 0.858 \\
\hline Business Differences & 3.974 & 1 & 4.55 & 0.597 \\
\hline
\end{tabular}

\section{2- Inferential statistics}

\section{2-1 Testing of Measurement Model}

In this step, the convergent and discriminant validity of the constructs are calculated by testing the measurement model.

Convergent validity reveals the measurement of one or some variables in different ways to investigate the correlation of constructs relationships (Carlson and Herdman, 2012). Regarding to confirm any construct in convergent validity, the Average Variance Extracted (AVE) amount should exceed 0.50 and the Composite Reliability (CR) should be higher than 0.70 (Hair et al., 2014; Fornell \& Larcker, 1981). As consequences of the measurement model testing demonstrate that all the amount of AVE, CR and the factor loadings were in the acceptable range. Therefore, the convergent validity of the model was acknowledged.

Table 3: Measurement Model Analysis 
International Conference on Research in Management \& Economics Serbia | Belgrade | December 15-17, 2018

\begin{tabular}{|c|c|c|c|c|c|c|}
\hline Constructs & Questions & $\begin{array}{l}\text { Factor } \\
\text { Loadings }\end{array}$ & $\begin{array}{l}\mathrm{t}- \\
\text { value }\end{array}$ & $\begin{array}{l}\text { AVE (Average } \\
\text { Variance } \\
\text { Extracted) }\end{array}$ & $\begin{array}{l}\text { CR } \\
\text { (Composite } \\
\text { Reliability) }\end{array}$ & $\begin{array}{l}\text { Cronbach's } \\
\text { Alpha }\end{array}$ \\
\hline \multirow{9}{*}{$\begin{array}{l}\text { Human } \\
\text { capital }\end{array}$} & Q 1 & 0.793 & 22.442 & \multirow{9}{*}{0.646} & \multirow{9}{*}{0.942} & \multirow{9}{*}{0.932} \\
\hline & Q 2 & 0.758 & 18.393 & & & \\
\hline & Q 3 & 0.697 & 13.935 & & & \\
\hline & Q 4 & 0.855 & 40.565 & & & \\
\hline & Q5 & 0.816 & 33.920 & & & \\
\hline & Q 6 & 0.858 & 36.972 & & & \\
\hline & Q7 & 0.847 & 45.015 & & & \\
\hline & Q 8 & 0.757 & 17.670 & & & \\
\hline & Q9 & 0.840 & 26.421 & & & \\
\hline \multirow{10}{*}{$\begin{array}{c}\text { Export } \\
\text { performance }\end{array}$} & Q 10 & 0.818 & 30.860 & \multirow{10}{*}{0.719} & \multirow{10}{*}{0.962} & \multirow{10}{*}{0.956} \\
\hline & Q 11 & 0.823 & 46.320 & & & \\
\hline & Q 12 & 0.878 & 45.841 & & & \\
\hline & Q 13 & 0.767 & 21.972 & & & \\
\hline & Q 14 & 0.846 & 42.571 & & & \\
\hline & Q 15 & 0.833 & 34.091 & & & \\
\hline & Q 16 & 0.889 & 51.131 & & & \\
\hline & Q 17 & 0.866 & 43.749 & & & \\
\hline & Q 18 & 0.836 & 33.807 & & & \\
\hline & Q 19 & 0.858 & 43.922 & & & \\
\hline \multirow{4}{*}{$\begin{array}{l}\text { Cultural } \\
\text { differences }\end{array}$} & Q 20 & 0.859 & 48.634 & \multirow{4}{*}{0.719} & \multirow{4}{*}{0.911} & \multirow{4}{*}{0.869} \\
\hline & Q 21 & 0.854 & 48.087 & & & \\
\hline & Q 22 & 0.813 & 31.538 & & & \\
\hline & Q 23 & 0.866 & 53.005 & & & \\
\hline \multirow{4}{*}{$\begin{array}{l}\text { Business } \\
\text { differences }\end{array}$} & Q 24 & 0.822 & 31.119 & \multirow{4}{*}{0.715} & \multirow{4}{*}{0.909} & \multirow{4}{*}{0.867} \\
\hline & Q 25 & 0.854 & 54.953 & & & \\
\hline & Q 26 & 0.844 & 41.325 & & & \\
\hline & Q 27 & 0.863 & 44.707 & & & \\
\hline
\end{tabular}

For analysis of discriminant validity, the Fornell-Larcker criterion is used. According to this criterion, the square root of AVE amount for each construct should be higher than bilateral correlations between that construct and all other constructs (Hair et al., 2014: Fornell \& Larcker, 1981). The measurement model results displayed that the Fornell-Larcker criterion was satisfied for all the constructs of the model (Table 4 ) and discriminant validity was accepted. 
International Conference on Research in Management \& Economics

Serbia | Belgrade | December 15-17, 2018

Table 4: Measurement model analysis

\begin{tabular}{||l|l|l|l|l||}
\hline variables & $\begin{array}{l}\text { Human } \\
\text { Capital }\end{array}$ & $\begin{array}{l}\text { Export } \\
\text { Performance }\end{array}$ & $\begin{array}{l}\text { Cultural } \\
\text { Differences }\end{array}$ & $\begin{array}{l}\text { Business } \\
\text { Differences }\end{array}$ \\
\hline \hline Human Capital & $\mathbf{0 . 8 4 7 9}$ & 0 & 0 & 0 \\
\hline $\begin{array}{l}\text { Export } \\
\text { Performance }\end{array}$ & 0.4855 & $\mathbf{0 . 8 4 7 9}$ & 0 & 0 \\
\hline $\begin{array}{l}\text { Cultural } \\
\text { Differences }\end{array}$ & 0.4725 & 0.6941 & $\mathbf{0 . 8 4 7 9}$ & 0 \\
\hline $\begin{array}{l}\text { Business } \\
\text { Differences }\end{array}$ & 0.5171 & 0.6252 & 0.5632 & $\mathbf{0 . 8 4 5 2}$ \\
\hline
\end{tabular}

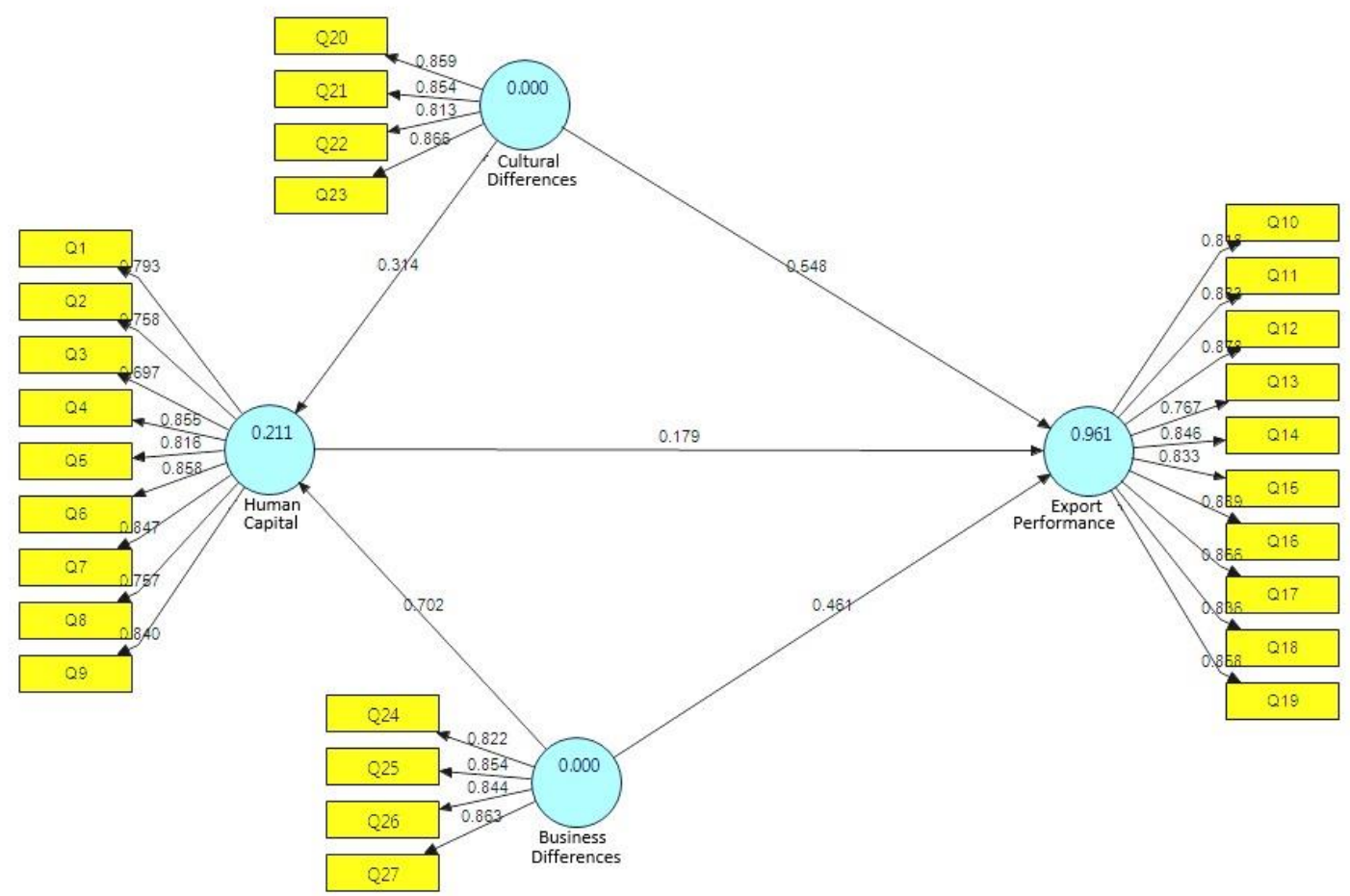

Fig. 2: Measurement model analysis

\section{2-2 Testing of Structural Model}

Initially, the coefficient of determination $\left(R^{2} P\right) P$ has been computed to find out if outcomes are repeated well by the model, according to the proportion of generic variance of data obtained which clarified by the model. the coefficient of determination ranges are from 0 to 1 which (R9T $\left.2_{P}\right) P$ amount around $0.75,0.50$, or $9_{T} 0.25$ for innate latent variables in the structural model accounted for remarkable, medium, or shortage, sequentially (Chin 1998). 
International Conference on Research in Management \& Economics

Serbia | Belgrade | December 15-17, 2018

Finally, by using a non-parametric test called Stone-Geisser and also the blindfolding approach, predictability of the research model has been evaluated. In this way, CV.redundancy $\left(Q^{2} P\right) P$ and $\mathrm{CV}$.communality $\left(\mathrm{H}^{2}\right)$ measures have been calculated. The model has predicative relevance if $\mathrm{H}^{2}$ and $\mathrm{Q}^{2}$ would be above zero (Guenzi et al., 20

09).

Table 5: Coefficient of Determination of the research model

\begin{tabular}{|l|c|c|c|}
\hline Constructs & $\mathrm{R}^{2}$ (Coefficient of Determination) & CV. Redundancy $\left(\mathrm{Q}^{2}\right)$ & $\mathrm{CV}$. Communality $\left(\mathrm{H}^{2}\right)$ \\
\hline Human Capital & - & 0.130 & 0.646 \\
\hline $\begin{array}{l}\text { Export } \\
\text { Performance }\end{array}$ & 0.961 & 0.684 & 0.704 \\
\hline $\begin{array}{l}\text { Cultural } \\
\text { Differences }\end{array}$ & - & 0.719 & 0.719 \\
\hline $\begin{array}{l}\text { Business } \\
\text { Differences }\end{array}$ & - & 0.715 & 0.715 \\
\hline
\end{tabular}

\section{Results}

In continuous, the structural model is tested by path coefficients and Student's $t$-test the research model.

The relationship testing results are based on bootstrapping (Repeated and sequential sampling) to test the statistical significance of each path coefficient by using t-tests, (Chin, 1998).

The acceptable range for $\mathrm{t}$-value is higher than 1.96 or lower than -1.96. If $\mathrm{t}$-value would be more than $\mathbf{1 . 9 6}$ for each path, it can be concluded that this path is significant and the hypothesis is approved at the error level 0.05 . The results of the Hypotheses test analysis are presented in Table 6. According to Table 6, hypotheses 1 to 5 are accepted with level of significance of 95\% and also hypotheses 6 and 7 are not accepted.

Table 6: Hypothesis test results

\begin{tabular}{|c|c|c|c|c|c|c|}
\hline \multirow[b]{2}{*}{ hypothesis } & \multicolumn{3}{|c|}{ construct } & \multirow{2}{*}{$\begin{array}{l}\text { path coefficient } \\
\text { (ß) }\end{array}$} & \multirow[b]{2}{*}{ t-value } & \multirow[b]{2}{*}{ results } \\
\hline & $\begin{array}{l}\text { independent } \\
\text { variable }\end{array}$ & $\begin{array}{l}\text { dependent } \\
\text { variable }\end{array}$ & $\begin{array}{l}\text { mediator } \\
\text { variable }\end{array}$ & & & \\
\hline 1 & $\begin{array}{l}\text { Cultural } \\
\text { Differences }\end{array}$ & $\begin{array}{l}\text { Human } \\
\text { Capital }\end{array}$ & - & 0.314 & 3.204 & Accepted \\
\hline 2 & $\begin{array}{l}\text { Business } \\
\text { Differences }\end{array}$ & $\begin{array}{l}\text { Human } \\
\text { Capital }\end{array}$ & - & 0.702 & 9.407 & Accepted \\
\hline
\end{tabular}


International Conference on Research in Management \& Economics

Serbia | Belgrade | December 15-17, 2018

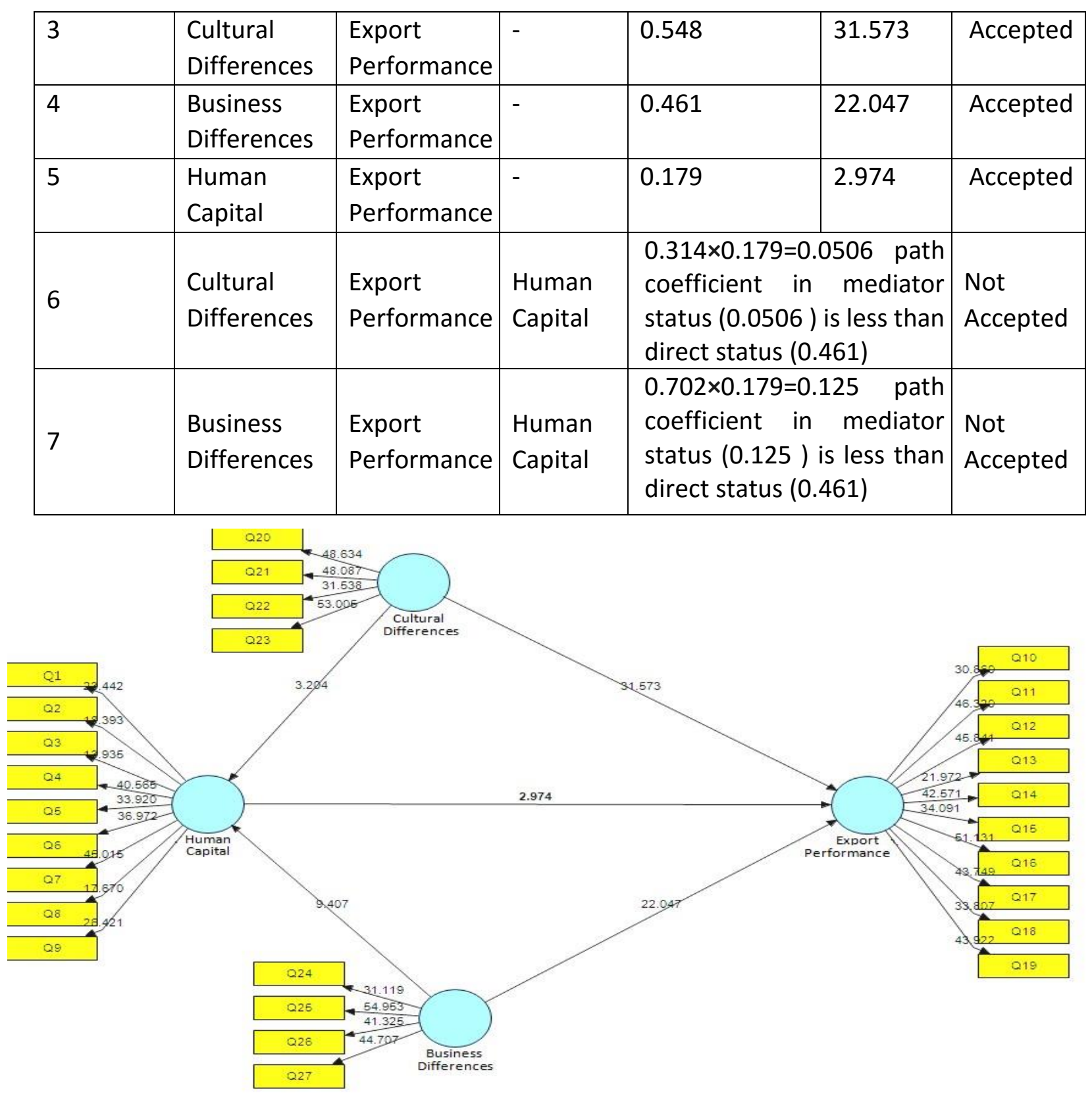

Fig. 3: Structural model analysis with t-values

Discussion and conclusion

According to the results obtained from structural equation, hypotheses 1 to 5 have been confirmed and hypotheses 6 and 7 have not been approved. In this regard, relations between cultural and business differences with human capital and export performance have been confirmed separately and there is a confirmed significant relation between human capital and export performance. Meanwhile, the role of mediator human capital among cultural and business differences and export performance of companies has not been accepted. Thriving 
International Conference on Research in Management \& Economics

Serbia | Belgrade | December 15-17, 2018

export performance is comprised of various levels and complex structure in an extended range that requires special attention (Lages et al., 2005). Hence, successful export performance depends on the expectations of the organization's managers, organizational targeting and existing constraints. Accordingly, companies decide to export globally based on available resources and facilities in the internal environment (such as human capital) and limitations and opportunities in the external environment (such as cultural differences and the import laws and regulations of the countries) (Griffith and Dimitrova, 2014). In recent years, Iranian domestic appliances companies have signed agreements with foreign partners to improve the quality of their products and develop technological sectors of industries which have had a significant and positive impact on their worldwide market share. It can be concluded that the largest share of export for Iranian household appliances companies in export performance is the neighbouring countries of Iran. Based on economic sanctions imposed on Iran's trade over the past years and regarding to decline probable business ventures, countries around Iran are the best commercial target for Iranian companies because of being positive bilateral cultural and political relationship.

\section{References}

Ali, M., Egbetokun, A., and Memon, M. H. (2018) "Human Capital, Social Capabilities and Economic Growth". Economics, Vol. 6, No. 2, pp 1-18.

Boskov, T., and Lazaroski, S. (2011) "Globalization, trade and business". In: Proc. of the Fourth International Scientific Conference on"Economic \& Social Challenges 2011, Globalization and Sustainable Development", Tirana, Albania.

Carlson, K. D., Herdman, A. O. (2012) "Understanding the Impact of Convergent Validity on Research Results". Organizational Research Method, Vol. 15, No. 1, pp 17-32.

Chin, W. W. (1998) "Issues and opinions on structural equation modeling". Management Information Systems Quarterly, Vol. 22, pp 7-16.

Contractor, F. J., and Mudambi, S. M. (2008) "The influence of human capital investment on the exports of services and goods: An analysis of the top 25 services outsourcing countries". Management International Review, Vol. 48, No. 4, pp 433-445.

De Toni, D., Milan, G. S., Saciloto, E. B., and Larentis, F. (2017) "Pricing strategies and levels and their impact on corporate profitability". Revista de Administração, Vol. 52, No. 2, pp 120-133. Fornell, C., and Larcker, D. F. (1981) "Evaluating structural equation models with unobservable variables and measurement errors". Journal of Marketing Research, Vol. 18, pp 39-50. Ghosh, B. (2011) "Marketing Cultural Changes and Challenges in the Era of Globalization: The Case of India". Journal of Developing Societies, Vol. 27, No. 2, pp 153-175.

Gilfoil, D. M., Aukers, S. M., and Jobs, C. G. (2015) “Developing and Implementing a Social Media Program While Optimizing Return on Investment - An MBA Program Case Study". American Journal of Business Education, Vol. 8, No. 1, pp 31-48. 
International Conference on Research in Management \& Economics Serbia | Belgrade | December 15-17, 2018

Goldin, C. (2016) "Human Capital", Handbook of Cliometrics. Heidelberg, Germany: Springer Verlag.

Griffith, D. A., and Dimitrova, B. V. (2014) "Business and Cultural Aspects of Psychic Distance and Complementarity of Capabilities in Export Relationships". Journal of International Marketing, Vol. 22,No. 3, pp 50-67.

Guenzi, P., Georges, L., and Pardo, C. (2009) "the impact of strategic account managers' behaviors on relational outcomes: An empirical study". Industrial Marketing Management, Vol. 38, pp 300311.

Guffey, M. E. (2005) "Business Communication: Process and Product" 5th Gülsoy Ed, Thomson, South-Western College Publishing.

Gülsoy Guenzi, T., Özkanlı. Ö., and Lynch. R. (2011) "The role of innovation in the effective international

expansion of an emerging-country firm: The case of Arçelik". Social and Behavioral Sciences, Vol. 41, pp 116-129.

Hair, Jr. J. F., Hult, G. T. M., Ringle, C., and Sarstedt, M. (2014) "A primer on partial least squares structural equation modeling (PLS-SEM)". Sage Publications.

Haq, M., Luqman, M. (2014) "The contribution of international trade to economic growth through human capital accumulation: Evidence from nine Asian countries". Cogent Economics \& Finance, Vol. 2, No. 1,pp 1-13.

Hooker, J. N. (2012) "Cultural Differences in Business Communication". The Handbook of Intercultural Discourse and Communication.

Hoyer, W. D., Chandy, R., Dorotic, M., Krafft, M. and Singh, S. S. (2010), "Consumer cocreation in new product development". Journal of Service Research, Vol. 13 No. 3, pp. 283-296.

Kahiya, E. T., and Dean, D. L. (2014) "Export performance: multiple predictors and multiple measures

approach". Asia Pacific Journal of Marketing and Logistics, Vol. 26, No. 3, pp 378-407. Kilavuz, E., and Topcu, B. A. (2012) "Export and Economic Growth in the Case of the Manufacturing Industry: Panel Data Analysis of Developing Countries". International Journal of Economics and Financial issues, Vol. 2, No. 2.

Koklic, M. K., and Vida, I. (2009) "A Strategic Household Purchase: Consumer House Buying Behavior".

Managing Global Transitions, University of Primorska, Faculty of Management Koper, Vol. 7, No. 1 , $\mathrm{pp}$

75-96.

Konya, I. (2006) "Modeling Cultural Barriers in International Trade". Review of International Economics, Vol. 14, No. 3, pp 494-507.

Kutan, A. M., and Vuksic, G. (2007) “Foreign Direct Investment and Export Performance: Empirical Evidence". Comparative Economic Studies, Vol. 49, No. 3, pp 430-445.

Lages, L. F., Lages, C., \& Lages, C. R. (2005) "Bringing export performance metrics into annual reports: the APEV scale and the perfex scale". Journal of International Marketing, Vol. 13, No. 3, $\mathrm{pp}$

79-104. 
International Conference on Research in Management \& Economics Serbia | Belgrade | December 15-17, 2018

Leonidou, L. C. (2004) "An analysis of the barriers hindering small export development". Journal of Small Business Management, Vol. 42, No. 3, pp 279-303.

The International Conference on Research in Management \& Economics, 15th -17th December 2018 / Belgrade, SerbiaLevitt, T. (1983) "The Globalization of Markets". Harvard Business Review, Vol. 61, No. 3, pp 92-102.

Macionis, J. J., and Gerber, L. M. (2011) "Sociology", Pearson Education Canada. Malhotra, N. K., and Peterson, M. (2001) "Marketing research in the new millennium: Emerging issues and trends". Marketing Intelligence \& Planning, Vol. 19, No. 4, pp 216-235.

Menezes, C. (2014) "Impact of culture in International Business - An empirical study of Multinational Businesses in India". International Research Journal of Business and Management, Vol. $\begin{array}{llll}\text { VII, } & \text { No. } & 12, & \text { pp }\end{array}$ Mitic, B., and Ivic, M. (2016) "The Impact of Foreign Direct Investment on Export Performance: Case of European Transition Economies". Independent Journal Of Management \& Production (IJM\&P).

Munch, J., and Schaur, G. (2014) "The Effect of Export Promotion on Firm-Level Performance".American Economic Journal: Economic Policy, Vol. 10, No. 1, pp 357-387.

$\mathrm{Ng}, \mathrm{A}$. H., and Hynie, M. (2014) "Cultural differences in indecisiveness: The role of naïve dialecticism". Personality and Individual Differences, Vol. 70, pp 45-50.

Samimi, P., and Janatabadi H. S. (2014) "Globalization and Economic Growth: Empirical Evidence on the Role of Complementarities". PLoS ONE, Vol. 9, No. 4, pp 92-102.

Shome, R. (2012) "Mapping the Limits of Multiculturalism in the Context of Globalization". International Journal of Communication, Vol. 6, pp 144-165.

Souleh, S. (2014) "The impact of Human Capital Management on the Innovativeness of research Center: The Case of Scientific Research Centers in Algeria". International Journal of Business \& Management, Vol. II,No. 4, pp 80-96.

Tesfom, G., and Lutz, C. (2006) "A classification of export marketing problems of small and medium sized manufacturing firms in developing countries". International Journal of Emerging Markets, Vol. 1, No. 3,pp 262-281.

Zakaria, M. (2014) "Effects of Trade Liberalization on Exports, Imports and Trade Balance in Pakistan: A Time Series Analysis". Prague Economic Papers, University of Economics, Prague, Vol. 1, pp 121-139. 